\title{
Twenty Years of Cooperation between Botanists of the Goethe-University Frankfurt (Germany) and of West African Universities
}

\author{
R. Wittig, S. Guinko, K. Hahn-Hadjali, B. Sinsin, G. Zizka, S. Dressler, A. Thiombiano
}

Summary: The year 1989 represents the starting point of the cooperation between botanists of the Goethe-University in Frankfurt (Germany) and of the University of Ouagadougou (Burkina Faso). Some years later, the University of Abomey-Calavi (Benin) joined the cooperation. This paper gives an overview on joint projects, resulting publications and theses, and on other achievements of this fruitful cooperation, which meanwhile also comprises partners of Ivory Coast, Niger and Senegal.

Key words: bibliography, ethnobotany, savanna, vegetation

\section{Vingt ans de coopération entre botanistes de L'Université J.W.Goethe, Francfort (Allemagne) Et des UNIVERSITÉS OUEST-AFRICAINES}

Résumé: En 1989, des botanistes de l'Université Goethe à Francfort (Allemagne) et de l'Université Ouagadougou (Burkina Faso) on commencé leur premier projet de coopération. Quelques années après, l'Université Abomey-Calavi (Bénin) est venue s'associer à leur coopération. Le présent travail donne un résumé des projets communs, en indiquant les publications, mémoires (de doctorat, diplôme et autres examens) et autres résultats provenant de cette féconde coopération, qui implique entre-temps aussi des partenaires du Cote d'Ivoir, du Niger et du Sénégal.

Mots clés: bibliographie, ethnobotanique, savanne, végétation

\section{Zwanzig Jahre Zusammenarbeit zWischen BotanikeRn der Goethe-Universität Frankfurt (Deutschland) UND WESTAFRIKANISCHER UNIVERSITÄTEN}

Zusammenfassung: Im Jahre 1989 begann die Zusammenarbeit zwischen Botanikern der Goethe Universität Frankfurt (Deutschland) und der Universität Ouagadougou (Burkina Faso). Einige Jahre später schloss sich die Universität AbomeyCalavi (Benin) dieser Zusammenarbeit an. Die vorliegende Arbeit gibt einen Überblick über die gemeinsamen Projekte, die daraus resultierenden Publikationen und Examens-, Diplom- und Doktorarbeiten sowie über weitere Ergebnisse dieser fruchtbaren Zusammenarbeit, an der mittlerweile auch Partner aus Elfenbeinküste, Niger und Senegal beteiligt sind.

Schlagworte: Bibliographie, Ethnobotanik, Savanne, Vegetation

\section{INTRODUCTION}

In 1988, a contract of cooperation between the Universities of Frankfurt and Ouagadougou was signed. But it was not before the end of the year 1989, when the first author received a grant from the Deutsche Forschungsgemeinschaft (DFG) to join the Sonderforschungsbereich 268 (Collaborative Research Centre 268), that this contract became alive on the field of Botany. Therefore, we keep the year 1989 as the starting point of the cooperation between botanists of the Goethe-University Frankfurt (Germany) and the University of Ouagadougou (Burkina Faso). In a later phase of the SFB, the University of Abomey-Calavi (Benin) joined the cooperation. After the end of the SFB in 2001, new joint projects were started in which also partners from universities in Niger, Senegal and Ivory Coast are involved.

The interdisciplinary project SFB 268 was titled Kultur- und Sprachentwicklung im Naturraum Westafrikanische Savanne (Cultural development and history of language in the natural environment of the West African savannah). As it was the major goal of this interdisciplinary project to look for congruencies between, or influences of the landscape on, development of culture and language, the description and analysis of the landscape played an important role. Savanna landscapes, however, are mainly dominated and characterized by their vegetation. Therefore, vegetation science was urgently needed in this research program. But in West Af- rica vegetation does not only characterize the landscape, it is also of high importance for the livelihood. That is why, besides vegetation science, ethnobotany played a major role in the SFB 268.

Within West Africa, the SFB 268 focused on two countries: Nigeria and Burkina Faso. Although, from the viewpoint of the language, working in an English speaking country would have been much more convenient, Burkina Faso was chosen as the research country because it was politically much more stable than Nigeria. This decision was the starting point of a fruitful cooperation between botanists of the universities of Frankfurt and Ouagadougou, some years later also Abomey-Calavi (Benin) and Bobo-Dioulasso (Burkina Faso), recently comprising Niamey (Niger), Dakar (Senehal) and Abidjan (Ivory Coast).

Twenty years seem to be the right time span to look back and summarize what has been achieved by the cooperation with the main partners from Ouagadougou and Abomey-Calavi. But it is also of great importance to look into the future and to show the possibilities for a continuing cooperation. Therefore, this paper contains the following items (section):

- Joint projects (2),

- Publications (3),

- Theses originating from the cooperation (4),

- Joint publication series (5), 
- Data collection and data storing (6)

- Cooperation with the Research Institute Senckenberg (7),

- Future perspectives (8).

\section{JOINT PROJECTS}

In the past 20 years, the following six joint projects have been initiated between Frankfurt and Ouagadougou or Frankfurt, Ouagadougou and Cotonou:

- Collaborative Research Center 268 (SFB 268 : s. 2.1),

- Tropical Ecology Support Program of the GTZ: Ecology and use of Combretaceae in Burkina Faso (2.2),

- VW-Foundation Partnership program project: Savannas of the Sudanian Zone in Burkina Faso and Benin: Phytocoenoses and Phytodiversity (2.3),

- Biodiversity Transect Analysis (BIOTA West : s. 2.4),

- Tools for management and Sustainable Use of Natural vegetation in West Africa (SUN : s. 2.5),

- LOEWE-Zentrum Biodiversitäts- und Klima-Forschung (LOEWE center Biodiversity \& Climate Research; BiKF: s. 2.6).

Projects 2.1-2.3 meanwhile have ended, 2.4 and 2.5 will end in 2010, while 2.6 will continue until 2011. Two further projects are in preparation.

\subsection{Collaborative Research Center 268 (1989 - 2002)}

\subsubsection{General aims}

The central aim of the Collaborative Research Center 268 SFB 268 (Sonderforschungsbereich $268=$ SFB 268) was the investigation of all cultures of the West African savanna, of the natural landscapes in which these cultures have developed, and of correlations between natural and cultural systems. To achieve this goal, a team of archeologists, archaeobotanists, botanists, ethnologists, geographers and linguists studied the interactions between man and environment in past and present.

The prehistoric Homo sapiens depended strongly on its environment. Therefore, the development of culture should be influenced by the character of the environment. The different types of human culture existing today and having existed in a time span open to historic research are the result of a long lasting development. It cannot be assumed that cultures are exclusively formed by the natural area in which they exist today. Therefore, strategies of adaptations of cultures to changing environments were in the focus of the SFB 268.

The SFB 268 had its own publication series, called Berichte des Sonderforschungsbereiches 268 (Reports of the Collaborative Research Centre 268), of which 17 volumes appeared. Many of them had a focus on particular questions treated in the SFB which in these volumes were enlightened interdisciplinary. The final results of the SFB were summarized in a book titled Mensch und Natur in Westafrika (Man and Nature in West Africa, edited by ALBERT et al. 2004a). A popular version of the results was edited by REIKAT (2003) under the title Leben in Westafrika.

2.1.2 Aims and achievements of the botanical subproject Within the SFB two botanical groups from Frankfurt were involved: the former Institute of Botany (meanwhile Insti- tute of Ecology, Evolution and Diversity) and the Archaeobotany group of the Institute of Pre- and Proto-History. In the following the project of the former Institute of Botany is dealt with, the field of Archaeobotany is treated in a separate paper (NEUMANN 2009, this volume).

It was the aim of the botanical subproject to characterize and analyze in selected areas the reasons for the development of different savanna types by phytosociological and ethnobotanical investigations in order to allow a deeper understanding of the landscape which is mainly dominated by vegetation. In its first and second phase (1989-1990, 1991-1993), the project focused on SE- and S-Burkina Faso, in particular the provinces of Gurma and Tapoa, and on the surrounding of Tenkodogo (province of Boulgou). In these phases, three $\mathrm{PhD}$ theses (Hahn, Kéré and Küppers) were initiated and one diploma thesis was prepared (MARTIN 1993). An overview of the results obtained so far was published by WITTIG et al. (1992), some particular results are described by BALLOUCHE et al. (1993), KÜPPERS \& MÜLleR-HAUdE (1993), Mischung et al. (1993), HAHn \& WitTig (1995), Kéré \& Wittig (1995), KüPPERS \& WitTig (1995) WitTig \& MARTIN $(1995,1998)$.

The main questions were:

- How do habitat conditions and land use practices influence species composition and vegetation?

- Are there relations between vegetation pattern and types of land use ?

- How does the selected use of particular species influence the vegetation?

During the third phase (1994-1996), the above mentioned PhD-theses were finished (HAHN 1996, KÉRÉ 1996 and KÜPPERS 1998) and Thiombiano started the research for his thèse de 3è cycle. Additionally, two diploma-theses were prepared (ATAHOLO 1995 and EICHHORN 1995). The research area within Burkina Faso area was expanded, now including the province of Sissili, in particular the region of Tiébelé mainly inhabited by the Kassena, and the region of To inhabited by the Nuna. Some particular research was carried out in northern Nigeria (in the area of the Kanuri, Bura, Tula and Tangale).

Some results were published by Ataholo \& WitTig (1995), BrAUN et al. (1995/1996, 1996, 1997), EICHHORN et al. (1996), Kerber et al. (1996), Kéré \& Ritz-Müller (1995), Sturm (1995, 1997a,b; 1998a,b), STURM et al. (1996), WiTTIG et al. (1998).

In the fourth phase (1997-1999), the research area was expanded again, now also including Benin. The research aim generally remained the same as in the third phase, however now focusing on the following points.

- Development and characteristic of different savanna types in different zones in relation to habitat conditions and land-use interferences,

- Developments and dynamics of park savannas and agroforestry systems (German: Kulturbaumlandschaften),

- Composition of ruderal and segetal vegetation in different vegetation zones.

During this phase two diploma-theses were prepared (ВöHM 1998, Denschlag 1998). The start of the PhD theses of Krohmer, Müller and Sieglstetter (see below) also fell into 
this phase. Some particular results are reported by BRAUNYAO \& Hahn-Hadjali (1999), Braun-YaO et al. (2000), Hahn-Hadjali \& Schmid (1999), Hahn-Hadjali et al. (2001), ReiKAT et al. (2001), Schmid et al. (2001), STURm (1999, 2001a, b), Sturm et al. (1999), WitTig et al. (2000a).

In the fifth and last phase of the SFB (2000-2002) research concentrated on:

- savanna vegetation in northern Benin and its value as indicator for land-use changes,

- species composition and dynamics of the Sahelian vegetation in Burkina Faso,

- environmental perception and classification of Fulani groups in different vegetation zones of Burkina Faso and Benin.

Parts of the results were published by NeumanN et al. (2004), Pelzer et al. (2004), Albert et al. (2004b), DemiRAG \& Krohmer (2004) and Lentz \& Sturm (2004). Summaries and interdisciplinary evaluations of the results were given by WitTig et al. (2000b, 2002).

During or shortly after the end of this phase, the PhD theses of Ataholo (2001), Sieglstetter (2002). Müller (2003) and Krohmer (2004) were written. Parts of these theses were published by MüLLER \& WiTTIG $(2002,2004)$, Sieglstetter \& Wittig (2002), WitTig et al. (2002, 2004a, 2006), Krohmer (2002, 2005, 2010), Krohmer \& SigSLETTER (2002), KROHMER et al. (2006a).

\subsection{Tropical Ecology Support Program of the GTZ: Ecology and Use of Combretaceae in Burkina Faso (1996 - 1998)}

Overuse and degradation of natural resources constitute serious barriers to development. For the protection of remaining resources an ecologically sustainable resource management with participation of the local population is essential. For sustainable silvicultural management of savannas and forests, profound knowledge of the ecology and utilization of local tree species is of crucial importance. Thus, the objective of this study has been to provide comprehensive information on the ecology, the regenerational dynamics and the use of several widely distributed local tree species of the family Combretaceae (Combretum aculeatum, C. glutinosum, C. micranthum, C. nigricans). In addition, options and simple methods for the use of these species against erosion and for restoration of degraded areas were developed and propagated.

The results show the high ecological and socio-economic importance of the investigated Combretum species. They are among the most common woody plants in the Sudano-Sahelian zone and play an important role as pioneer species on dry and degraded sites. Because of their enormous regeneration potentials (root suckers, stump shoots) they are well adapted to the traditional system of exploitation. A regulated coppice forest management is possible and will probably further raise the productivity of the species. For the recultivation of degraded clearings, plantings with $C$. aculeatum and C. micranthum as well as direct sowing of $C$. aculeatum have proven to be successful.
Thus this study stresses the crucial role of local tree species for sustainable resource management in the West African Sahelian countries. Particularly, the very common Combretum species, which are exceptionally well adapted to the traditional exploitation systems and to the climatic conditions, can contribute in manifold ways to the preservation of resources, especially at problematic localities. Therefore, enhancement of the state of these species and other local tree species as well as their increased consideration are imperative to an improved conception of ecologically sound developmental cooperation projects.

The following publications partly or entirely result from this project: Thiombiano et al. (1996, 1997, 1998, 1999, 2002, 2003), KÉRÉ \& THIOMBIANo (1999a,b).

\subsection{VW-Foundation Partnership Program Project: Savannas of the Sudanian Zone in Burkina Faso and Benin: Phytocoenoses and Phytodiversity (2002 - 2005)}

The project aimed at contributing to a better knowledge of the savanna phytocoenoses in the Sudanian Zone of Burkina Faso and Benin by carrying out phytosociological inventories in protected areas and mountain chains belonging to the most diverse and least studied areas in these countries. Furthermore, the development of uniform methods of investigation, evaluation and vegetation classification focused on improving the comparability of results and for uniform vegetation mapping of both countries, which are very important with regard to conservation and more sustainable use. Also training of African junior scientists as well as the establishment and intensification of the close south-southnorth co-operation between the partners of the Universities of Ouagadougou/Burkina Faso, Abomey-Calavi/Benin and Frankfurt/Germany was sought via workshops, regular meetings and common field work. In addition, the expansion of the National Herbarium of Burkina Faso was planned for improving the basis for floristically exact determination and improvement of students' education.

Through the project activities a deeper knowledge of underinvestigated species rich areas in Burkina Faso and Benin was achieved for improving protection measures and management of these important areas with a high phytodiversity. For the first time sound data exist for these areas: 34 vegetation units were described in their relationship to topography, soil and anthropogenic impact MBAYNGONE et al. (2008a, b, c, d). Two PhD theses were prepared (MBAYNGONE 2007, WALA 2004).

Furthermore methods for vegetation inventories and classification were harmonized and standardized between the partner countries, which is indispensable for comparison of all vegetation data on national and regional levels in regard to sustainable use and conservation of natural resources and developing of management plans. However, it became obvious that the development of a synsystematical system valid for West Africa needs more time for data compilation and participation of scientists from several countries of the region. In this regard, a joint vegetation data base would be the next step for collecting all phytosociological data and identifying less investigated vegetation types for further detailed inventories. 
The aim of deepening the inter-African cooperation was extremely successful and was going far beyond the original intension of exchanging only between the implicated project partners. The south-south-network was extended by inviting to the workshops not only scientists from the project Universities but also scientists from other facilities (e.g. forest ministry, NGOs) and other countries. Furthermore, the PhD students sponsored by the project originate from other WestAfrican countries (Chad, Togo). They are both now working at their Universities as staff members so that a long term cooperation between scientists of these countries is guaranteed.

The joint workshops, excursions, exchange meetings and the summer school proved to be very important tools for intensifying the interdisciplinary and cross-country collaboration and networking. Even in the time of web and e-mailcommunication facilities, personal contact is most important for a functioning dynamic collaboration. The opportunity for junior scientists of the African countries to participate actively in these workshops for presenting and openly discussing their research was an outstanding opportunity and was highly appreciated by all participants.

\subsection{BIOTA}

\subsubsection{General goals of the all-encompassing BIOTA AFRICA program}

Within an interdisciplinary, integrative approach using standardized methods the network BIOTA West, BIOTA East and BIOTA South aims to analyse anthropogenic changes in biodiversity along climate gradients in representative sectors of the respective part of Africa. Goal of the program is to acquire a sound basis for a practice oriented and sustainable biodiversity management.

The partners from the University of Frankfurt, Ouagadougou and Abomey-Calavi are part of the BIOTA West network. Facing the specific ecological, environmental and socio-economic problems in West Africa, BIOTA-West contributes in an interdisciplinary, integrative, and participatory approach to this challenge with the goal of:

- identifying the drivers and processes leading to biodiversity loss,

- developing methods for the preservation of biodiversity on various scales integrating scenarios on the effects of global change,

- creating and implementing tools that contribute to the sustainable use of biodiversity.

\subsubsection{Aims and achievements of Subproject W11/BIOTA Frankfurt}

Subproject W11 (named BIOTA Frankfurt in the third phase) comprises the three partner Universities with the disciplines of vegetation ecology and remote sensing/pedology as well as botanists from the Senckenberg research institute and ethnologists from the University of Mainz (the latter for phase I and II only).

\section{Phase I (2001-2004) and Phase II (2004-2007)}

Considering the rapid changes in species diversity which have been observed in the West African savanna, research on the dynamics of phytodiversity in this zone is of special importance. The main objective of the project is to analyze and evaluate current and historical changes in phytodiversity along a climatic gradient under different utilization conditions. The investigations focus particularly on the identification of various human influences and the consequences of the anthropogenically altered vegetation dynamics for the local populations. By this research a better basis for developing sustainable use concepts and implementing conservation approaches is created. The investigations are carried out in an interdisciplinary approach including the disciplines of botany, pedomorphology, remote sensing, modelling, ethnology and socio-economy. They included on one hand the documentation and analysis of different temporal and spatial diversity patterns on different scales and on the other hand, by ethnobotanical and socio-economic investigations, the identification of various human influences and the consequences of vegetation dynamics for the local population. In three vegetation zones (Sahel-, Northern and Southern Sudanian Zone) representative landscape areas with different use intensities were investigated. Parts of the results were published by OuEDRAOGO RL et al. (2005), WitTig et al. (2004a, b, 2006), Wittig (2005a, b), Hahn-Hadjali et al. (2006a, b), Ouedraogo A et al. (2006a, b, c), ThiombiANO et al. (2006), SchMidT et al. (in press), GNOUMOU et al. (2008), KÖNIG et al. (2008a, b). In these phases several PhD and Diploma/DEA-thesies were prepared (see Table 1).

An important source for the analysis of diversity changes are also collection data from the region. For a more effective use of phytodiversity relevant data, the West African plant collections in Frankfurt and Burkina Faso were treated, digitized and linked to other data bases (see section 7).

By this interdisciplinary, participatory and actor-oriented approach, it was aspired to extend the research results towards the practical application of local use and conservation concepts. The interdisciplinary approach is divided into eight workpackages:

-WP1: Vegetation and land use mapping: analysis of spatial and temporal vegetation patterns;

-WP2: Phytodiversity dynamics in biodiversity observatories;

-WP3: Pedisediments, bioturbation and biodiversity;

-WP4: Indicator species;

-WP5: Socio-cultural dimension of plant diversity and ethnobotany;

-WP6: Regeneration of degraded sites;

-WP7: Resources protection measures: botanical gardens;

-WP8: Development and digitisation of collections, access to and utilisation of collection and observation data.

\section{Phase III (2007-2010)}

In phase III, entitled "Scientific support for conservation and sustainable use of biodiversity" the Frankfurt group focuses on the "Analysis, management concepts and application for conservation and sustainable use of natural resources".

The aim is to complete the various research activities started in phase I and II and to develop products and tools for application issues. Thus, the analysis and evaluation of biodiversity patterns continued for closing data gaps, particularly for protected areas (e.g. OUEDRAOGO O et al. 2009) and their surroundings as well as for termite mound vegetation along climatic gradients in Burkina Faso and Benin. Several 
PhD- and DEA-theses were prepared (OuEDRAOGO O 2009, Kaboré 2009, OuÉdraOgo J 2008, Soungalo 2008); some will be finalised in 2010 (Erpenbach, Deleke Koko, Traoré, Houehanou, Gnoumou). Research on the sustainable use and reintroduction of highly valued woody plant species for different use purposes with a focus on gender related aspects is continuing and monitoring of restoration of degraded systems by highly valued local woody species is pursued as well. Furthermore application and transfer into practise is stressed by studying locally protected areas such as sacred forests and other newly implemented structures and by fostering networking on this issue.

A main issue is the provision of a biodiversity atlas for decision making and practical application for various stakeholders in the concerned countries, resuming all the BIOTA-West results of the three phases. Botanical products for application such as a checklist of the vascular plants of Burkina Faso and a photo database are compiled by the Senckenberg research group (see section 7).

\subsection{SUN: Tools for Management and Sustainable Use of Natural Vegetation in West Africa (03/2007 - 08/2010)}

The aim of SUN (Tools for management and Sustainable Use of Natural vegetation in West Africa) is to develop new, practical management tools and concrete management actions for improved sustainable use of natural vegetation by combining scientific vegetation data, remote sensing and socio-economic information with local people's knowledge and needs. SUN includes West African (Burkina Faso, Benin, Niger, Senegal) and European scientists (Denmark, Germany, Italy) within vegetation-ecology, socio-economy, ethnoecology and remote sensing, all with experience in applied research.

SUN combines four types of activities:

- Action-oriented research specifically targeted towards management to improve the understanding of vegetation dynamics and their causal factors at the local scale (WP1) and to extrapolate these results from local to regional (West African) scale by use of a database of scientifically gathered vegetation data and remote sensing (WP2). Local knowledge and socio-economic studies will identify economic instruments to improve policies and redress impediments to sustainable use (WP3).

- Development of new decision support tools in order to organise and target already available scientific data and make them freely available via the internet. This includes a vegetation database, an overview of indicators of sustainable use and a GIS tool. These tools will be developed for scientists and decision makers who need a sound scientific basis for management decisions.

- Establishment of practical management and restoration actions in selected areas, planned in close collaboration between scientists and local people and carried out by local people with support from scientists.

- Dissemination at all levels (scientific community, decision makers, stakeholders, NGOs, aid development projects etc.)

Several PhD-theses will be available at the end of the project (Frankfurt: Jurisch, Schumann; Abomey-Calavi: Gou- wakinnou, Houessou; Ouagadougou: Kagambèga, Koadima, Nacoulma).

\subsection{LOEWE-Centre Biodiversity and Climate Research (BiK-F) (2008 - 2011)}

\subsubsection{Aims of the LOEWE-Centre BiK-F}

The mission of the LOEWE-Center Biodiversity and Climate Research Centre (Biodiversitäts- und Klima-Forschung) is to carry out internationally outstanding research on the interactions of organismal biodiversity and climate. Using a broad spectrum of state-of-the-art methods from satellite-supported remote sensing of climate, area and ecosystem reactions to advanced genomics and mass spectrometry, the scientists of the centre document and analyse past and present patterns and processes with the goal of providing reliable predictions of future developments. BiK-F integrates the multi-faceted expertise required for the in-depth investigation and management of climate-related biodiversity changes, including those that are relevant to the environment and health.

Several projects of the centre concentrate on savanna vegetation in West Africa. They are carried out in close collaboration of PhD students from Frankfurt with those of Ouagaodougou and Abomey-Calavi.

2.6.1.1 Project B2.7: Using niche-based modelling to assess the impact of climate and land use change on savannas and their ecosystem services, West Africa

The aim of this project is to analyse possible changes in savanna ecosystems in West Africa in relation to predicted land use and climate changes. Available plant diversity data from savannas are completed by current plant inventories along climatic gradients. Different future climate and landuse scenarios will be used in niche-based modelling approaches to assess the possible shifts of species ranges and species composition of savannas. By linking these results to parameters of ecosystem services (e.g. socio-economic data on the use value of species, biomass) the consequences of changes in savanna ecosystems caused by land use and climate change are quantified. Results will be combined with those of project F5.3 and transferred into tools targeted at decision-makers and stakeholders in the African countries.

2.6.1.2. Project F5.3: Quantifying ecosystem services and their changes in West African savannas

This project aims to assess and quantify the role of useful wild plant species as one of the important ecosystem services in West African savannas. Data on useful plant species and their value are compiled and approaches for evaluating the socio-economic and socio-cultural value of multipurpose use species are developed by considering subsistence and market values as well as cultural preferences. Results will be combined with those of project B2.7 to evaluate the possible implications of vegetation changes for ecosystem services in rural communities. The results will be translated into tools designed for the use of policy-makers and other stakeholders in the African countries, and they will be disseminated internationally. 


\section{Publications}

The bibliography of this paper contains all publications originating from the above mentioned projects or from other cooperations between the universities of Frankfurt and Ouagadougou, or Frankfurt, Oagadougou and Cotonou. The publications resulting from the cooperation with Senckenberg are also included. So far 114 publications have appeared. If a publication is related to a particular project this is indicated in brackets by the acronym used for the project in section two. Theses (see section 4) are not mentioned in the bibliography but listed in Table 1 .

\section{THESES}

Within the twenty years cooperation 34 DEA-, engineer-, or diploma-theses, $12 \mathrm{PhD}$-theses and one habilitation-theses (Thiombiano 2005) were prepared. The theses are listed in Table 1. For each theses it is indicated to which project it belongs and whether it has been partly or completely published. The 23 theses in preparation are listed separately (Table $2)$.

\section{Publication series}

In 1992, the two first authors of this paper started a joint bilingual (French/German) publication series, named Etudes sur la flore et la végétation du Burkina Faso et des pays avoisinants / Studien zur Flora und Vegetation von Burkina Faso und seinen Nachbarländern (Studies on flora and vegetation of Burkina Faso and neighboring countries).

As summarized in the preface to the first volume, the aim of this series was to amplify the publication opportunities for African scientists, and to have a possibility of rapid publication. Key words and authors of all contributions are listed in volume No 10. As the bilateral cooperation Burkina Faso/
Germany meanwhile has evolved to a multilateral cooperation between many African countries and Frankfurt, in 2008 the title of the series was changed into "Flora et Vegetatio Sudano-Sambesica". The reasons for this change are explained in the preface of the first volume of this series. The series started with No 11 to document the continuation of the "Etudes ...". These eleven volumes contain 51 articles. 25 are written from West African authors (Burkina Faso: 20; Benin: 2; Ivory Coast: 1; Niger: 1), 18 from European scientists (Germany: 16, Germany/France: 1, Netherlands: 1) and 10 are joint products of African and European authors (Burkina Faso/Germany: 6; Burkina Faso/France: 2, Burkina Faso/Denmark: 1; Niger/Belgium: 1).

\section{DATA COLLECTION AND DATA STORING}

Twenty years ago not more than about 1000 species of vascular plants were known from Burkina Faso. Thanks to the intensified investigation of the flora of Burkina Faso that was carried out since the start of the cooperation FrankfurtOuagadougou meanwhile more than 1,300 plants species are known. Of all species recorded in the frame of the project mentioned above, herbarium specimen were collected and deposited in the herbarium of the Senckenberg Museum of Frankfurt (see section 7) or in the herbarium at the University of Ouagadougou. In the frame of the SFB (collectors Ataholo, Eichhorn, Hahn-Hadjali (=Hahn), Kéré, Krohmer, Küppers, Martin, Müller, Sieglstetter) about 10,000 specimen from Burkina Faso and about 1,000 from Benin were added to the herbarium of Senckenberg. The archaeobotanical group (Neumann, Höhn, Karlheber: see NEUMANN 2010, this volume) collected another 3000 specimen. In the frame of BIOTA and SUN, scientists of the University of Frankfurt (Erpenbach, Jurisch, Schumann) depostited another 2,000 specimen at the Senckenberg herbarium.

\section{Table 1: Theses finalised}

University of Frankfurt (Germany), diploma-theses

\begin{tabular}{|l|l|l|l|l|}
\hline Year & Name & Title & Project & Publication \\
\hline 1993 & Martin, Regina & $\begin{array}{l}\text { Pflanzensoziologische und ethnobotanische Untersuchungen } \\
\text { der Dorfvegetation in der Provinz Tapoa - Burkina Faso }\end{array}$ & SFB & $\begin{array}{l}\text { WITTIG \& } \\
\text { MARTIN (1995, } \\
1998)\end{array}$ \\
\hline 1995 & Ataholo, Mandingo & $\begin{array}{l}\text { Pflanzensoziologische Untersuchungen der Segetalvegetati- } \\
\text { on in der Provinz Gourma (Burkina Faso) }\end{array}$ & $\begin{array}{l}\text { SFBHOLO \& } \\
\text { WITTIG (1995) }\end{array}$ \\
\hline 1995 & Eichhorn, Barbara & $\begin{array}{l}\text { Ackerunkrautvegetation in der Region Tiébélé in Burkina } \\
\text { Faso }\end{array}$ & SFB & $\begin{array}{l}\text { EICHHORN et al. } \\
(1996)\end{array}$ \\
\hline 1998 & Behlke, Linda & $\begin{array}{l}\text { Geobotanische Untersuchungen traditioneller agroforstlicher } \\
\text { Landnutzung in der Provinz Bougouriba (Burkina Faso) }\end{array}$ & GTZ & n.p. \\
\hline 1998 & Denschlag, Juliane. & $\begin{array}{l}\text { Ethnobotanische und pflanzensoziologische Untersuchungen } \\
\text { der Gehölzvegetation bei den Fulbe im Südosten von Burki- } \\
\text { na Faso }\end{array}$ & SFB & n.p. \\
\hline 1998 & ZeugmäHM (2001) \\
\hline
\end{tabular}


University of Frankfur (Germany), PhD-theses

\begin{tabular}{|l|l|l|l|l|}
\hline Year & Name & Title & Project & Publications \\
\hline 1996 & Hahn, Karen & $\begin{array}{l}\text { Die Pflanzengesellschaften der Savannen im Südosten Bur- } \\
\text { kina Fasos (Westafrika) }\end{array}$ & $\begin{array}{l}\text { SFB } \\
\text { (1998) }\end{array}$ \\
\hline 1996 & Kéré, Ulrike & $\begin{array}{l}\text { Die Dorf- und Savannenvegetation in der Region Tenkodogo } \\
\text { (Burkina Faso) }\end{array}$ & SFB & KÉRÉ (1998) \\
\hline 1998 & Küppers, Karin & Die Vegetation der Châine de Gobnangou & SFB & $\begin{array}{l}\text { KÜPPERS \& } \\
\text { WITTIG (1995) }\end{array}$ \\
\hline 2001 & Ataholo, Mandingo & $\begin{array}{l}\text { Pflanzensoziologische Untersuchungen der Segetalvegetati- } \\
\text { on in der Sudanzone Westafrikas }\end{array}$ & SFB & n.p. \\
\hline 2002 & Sieglstetter, Robert & $\begin{array}{l}\text { Wie die Haare der Erde - Vegetationsökologische und sozio- } \\
\text { kulturelle Untersuchungen zur Savannenvegetation der Süd- } \\
\text { sudanzone Westafrikas und ihrer Nutzung und Wahrnehmung } \\
\text { durch die ländliche Bevölkerung am Beispiel der Region } \\
\text { Atakora im Nordwesten Benins }\end{array}$ & SFB & $\begin{array}{l}\text { SIEGLSTETTER \& } \\
\text { WITTIG (2002) }\end{array}$ \\
\hline Müller, Jonas & $\begin{array}{l}\text { Zur Vegetationsökologie der Savannenlandschaften im Sahel } \\
\text { Burkina Fasos }\end{array}$ & SFB & $\begin{array}{l}\text { MÜLLER \& } \\
\text { WITTIG (2002, } \\
\text { 2004) }\end{array}$ \\
\hline
\end{tabular}

Senckenberg Reserach Institut, Frankfurt (Germany), Diploma-theses

\begin{tabular}{|l|l|l|l|l|}
\hline Year & Name & Title & Project & Publications \\
\hline 1998 & Grimmer, Andrea & $\begin{array}{l}\text { Morphologische und anatomische Untersuchungen an Vi- } \\
\text { tellaria paradoxa (Sapotaceae) }\end{array}$ & SFB & \\
\hline 2008 & Zwarg, Alexandra & $\begin{array}{l}\text { Flora und Vegetation auf Lateritkrusten im Südosten Burkina } \\
\text { Fasos }\end{array}$ & BIOTA & BIOTA \\
\hline 2009 & Kirchmair, Ivana & Flora und Vegetation auf Termitenhügeln in Nord-Bénin & B. \\
\hline
\end{tabular}

Senckenberg Reserach Institut, Frankfurt (Germany), PhD-theses

\begin{tabular}{|l|l|l|l|l|}
\hline Year & Name & Title & Project & Publications \\
\hline 2006 & Schmidt, Marco & $\begin{array}{l}\text { Pflanzenvielfalt in Burkina Faso - Analyse, Modellierung } \\
\text { und Dokumentation }\end{array}$ & $\begin{array}{l}\text { SCHMIDT et al. } \\
\text { (2008a), WITTIG } \\
\text { et al. (2004b, } \\
\text { 2006) }\end{array}$ \\
\hline
\end{tabular}

University Ouagadougou (Burkina Faso), DEA- and Engineers theses

\begin{tabular}{|c|c|c|c|c|}
\hline Year & Name & Title & Project & Publication \\
\hline 1992 & Thiombiano, Adjima & Les Combrétacées de la province du Gourma & SFB & $\begin{array}{l}\text { THIOMBIANO et } \\
\text { al. (1995) }\end{array}$ \\
\hline 1999 & Ouôba, Paulin & $\begin{array}{l}\text { La forêt de Lèra: structure, composition floristique et impact } \\
\text { socio-économique }\end{array}$ & SFB & \\
\hline 2007 & Gnoumou, Assan & $\begin{array}{l}\text { Etude de la flore et de la végétation du Parc Urbain Bangr- } \\
\text { Weoogo (Ouagadougou, Burkina Faso) }\end{array}$ & BIOTA & $\begin{array}{l}\text { GNOUMOU et al. } \\
(2008)\end{array}$ \\
\hline 2009 & Kaboré, G. Elice & $\begin{array}{l}\text { Diversité, dynamique et usages de la flore et de la végétation } \\
\text { de la Forêt Classée de Niouma }\end{array}$ & BIOTA & n.p \\
\hline 2008 & Ouédraogo, Issaka & $\begin{array}{l}\text { Diversité et utilisation des espèces ligneuses utiles de la ré- } \\
\text { gion du Nord du Burkina Faso : état des peuplements de } 5 \\
\text { espèces d'importance socio-économique }\end{array}$ & BIOTA & n.p \\
\hline
\end{tabular}




\begin{tabular}{|l|l|l|l|l|}
\hline 2008 & Soungalo, Soulama & $\begin{array}{l}\text { L'impact du Jatropha curcas sur la restauration du sol et la } \\
\text { résistance de cette plante à l'aridité }\end{array}$ & BIOTA & n.p \\
\hline 2009 & Ouédraogo, Ousmane & $\begin{array}{l}\text { Contribution à l'étude de la flore des falaises de Banfora } \\
\text { dans la forêt classée de Bérégadougou }\end{array}$ & BIOTA & n.p \\
\hline
\end{tabular}

University of Ouagadougou (Burkina Faso), PhD-theses and habilitation theses

\begin{tabular}{|l|l|l|l|l|}
\hline Year & Name & Title & Project & Publications \\
\hline 1996 & Thiombiano, Adjima & $\begin{array}{l}\text { Contribution à l'étude des Combretaceae dans les formations } \\
\text { végétales de la région Est du Burkina Faso }\end{array}$ & $\begin{array}{l}\text { SFB } \\
\text { GTZ 1 }\end{array}$ & $\begin{array}{l}\text { THIOMBIANO et } \\
\text { al. (1996; } 1997 ; \\
1998 ; 1999 ; \\
2001 ; 2002)\end{array}$ \\
\hline 2005 & $\begin{array}{l}\text { Thiombiano, Adjima } \\
\text { (habilitation thesis) }\end{array}$ & $\begin{array}{l}\text { Les Combretaceae du Burkina Faso : taxonomie, écologie, } \\
\text { dynamique et régénération des espèces }\end{array}$ & BIOTA & $\begin{array}{l}\text { SCHMIDT et al. } \\
(2005) ; \text { THI- } \\
\text { OMBIANO et al. } \\
(2006)\end{array}$ \\
\hline 2007 & Ouédraogo, Amadé & $\begin{array}{l}\text { Diversité et dynamique de la végétation ligneuse de la partie } \\
\text { orientale du Burkina Faso }\end{array}$ & BIOTA & $\begin{array}{l}\text { OUÉDRAOGO A } \\
\text { et al.(2006a,b,c) }\end{array}$ \\
\hline 2009 & Ouédraogo, Oumarou & $\begin{array}{l}\text { Phyto-écologie, dynamique et productivité des phytocoeno- } \\
\text { ses du Parc National d'Arly (Sud-Est du Burkina Faso) }\end{array}$ & BIOTA & $\begin{array}{l}\text { OUÉDRAOGO O } \\
\text { (2008; 2009) }\end{array}$ \\
\hline
\end{tabular}

University of Abomey-Calavi (Benin), theses DEA or Engineer (all not published)

\begin{tabular}{|c|c|c|c|}
\hline Year & Name & Title & Project \\
\hline 2001 & Wala, Kperkouma & $\begin{array}{l}\text { Typologie, structure et fonctionnement des agrosystèmes tra- } \\
\text { ditionnels dans la Préfecture de Doufélgou (Nord-Togo) }\end{array}$ & VW \\
\hline 2005 & Toyi, Mireille S & $\begin{array}{l}\text { Les principales espèces végétales utilisées dans la médecine } \\
\text { traditionnelle dans la Commune de Péhunco (République du } \\
\text { Bénin): mode d'exploitation, abondance et dynamique de ré- } \\
\text { génération }\end{array}$ & BIOTA \\
\hline 2007 & Ahoueya, Judicaël & $\begin{array}{l}\text { Contribution à l'analyse socio-économique de l'exploitation } \\
\text { des espèces de bois d'œuvre dans la Commune de Ouassa- } \\
\text { Péhunco }\end{array}$ & BIOTA \\
\hline 2007 & Bonou, Alice & $\begin{array}{l}\text { Estimation de la valeur économique des Produits Forestiers } \\
\text { Non Ligneux (PFNL) d'origine végétale dans le Village de } \\
\text { Sampéto (Commune de Banikoara) }\end{array}$ & SUN \\
\hline 2007 & $\begin{array}{l}\text { Deleke Koko, Kafui } \\
\text { Inès Edna }\end{array}$ & $\begin{array}{l}\text { Etude ethnobotanique et phytochimique des plantes galacto- } \\
\text { gènes utilisées en médecine traditionnelle dans la Zone Cy- } \\
\text { négétique de la Pendjari }\end{array}$ & BIOTA \\
\hline 2007 & Djibril, Bachirou & $\begin{array}{l}\text { Plantes gynécologiques: Disponibilité et valeur socio-écono- } \\
\text { mique des espèces les plus exploitées dans les terroirs river- } \\
\text { ains de la Zone Cynégétique de la Pendjari. }\end{array}$ & BIOTA \\
\hline 2007 & Dossou-Yovo, Hubert & $\begin{array}{l}\text { Contribution à la gestion durable des écosystèmes : Etude de } \\
\text { la diversité des plantes en relation avec les termites et ter- } \\
\text { mitières dans les champs, jachères, terrains riverains et Parc } \\
\text { National de la Pendjari. }\end{array}$ & BIOTA \\
\hline 2007 & Kossou, Eric & $\begin{array}{l}\text { Identification et caractérisation des formations végétales par- } \\
\text { courues par les éléphants d'Afrique (Loxodonta africana) } \\
\text { dans la Réserve de Biosphère de la Pendjari. }\end{array}$ & BIOTA \\
\hline 2007 & Lawani, Abelaziz & $\begin{array}{l}\text { Contribution du bois de feu aux moyens d'existence durable } \\
\text { des ménages riverains à la Réserve de Biosphère de la Pend- } \\
\text { jari : Axes Tanguiéta-Batia, Tanguiéta-Porga }\end{array}$ & BIOTA \\
\hline 2007 & $\begin{array}{l}\text { Monsi Agboka, Féli- } \\
\text { cienne }\end{array}$ & $\begin{array}{l}\text { Estimation des valeurs des produits non « commercialisés »: } \\
\text { cas des plantes utilisées pour soins gynécologiques dans les } \\
\text { terroirs de la Réserve de Biosphère de la Pendjari }\end{array}$ & BIOTA \\
\hline
\end{tabular}




\begin{tabular}{|c|c|c|c|}
\hline 2007 & $\begin{array}{l}\text { Orou Boun, Sabi Yari } \\
\text { Richard }\end{array}$ & $\begin{array}{l}\text { Evaluation des systèmes agro-forestiers dans les terroirs ri- } \\
\text { verains de la Zone Cynégétique de la Pendjari : Diversité des } \\
\text { espèces autochtones, diversité des essences exotiques et leur } \\
\text { viabilité, intégration agricole. }\end{array}$ & BIOTA \\
\hline 2007 & Tchibozo, Roland & $\begin{array}{l}\text { Problématique de l'exploitation du bois de feu: aspects bio- } \\
\text { logiques et aspects socio-économiques sur l'Axe Tanguiéta- } \\
\text { Porga }\end{array}$ & BIOTA \\
\hline 2008 & Avakoudjo, Julien & $\begin{array}{l}\text { Dégradation des terres et réhabilitation des écosystèmes dé- } \\
\text { gradés au Nord du Bénin : Etude de cas du Parc National du } \\
\text { W et des terroirs riverains dans la Commune de Karimama } \\
\text { (Bénin) }\end{array}$ & SUN \\
\hline 2008 & Azihou, Fortuné & $\begin{array}{l}\text { Adaptation de quelques espèces ligneuses et leurs compa- } \\
\text { gnes herbacées au changement de régime pluviométrique : } \\
\text { distribution spatiale, phénologie, écologie, phytosociologie, } \\
\text { viabilité. }\end{array}$ & BIOTA \\
\hline 2008 & Bonou, Alice & $\begin{array}{l}\text { Economic assessment of Non Timber Forest Products } \\
\text { (NTFP) in Sampéto, a surrounding village of the W National } \\
\text { Park in Banikoara district }\end{array}$ & SUN \\
\hline 2008 & Djogbenou, Anyse & $\begin{array}{l}\text { Etude comparative du niveau de conservation de quelques } \\
\text { espèces galactogènes, cosmétiques et tinctoriales dans les } \\
\text { terroirs riverains et la Zone Cynégétique de la Pendjari. }\end{array}$ & BIOTA \\
\hline 2008 & $\begin{array}{l}\text { Koukoubou, Gode- } \\
\text { froy }\end{array}$ & $\begin{array}{l}\text { Quantification et distribution spatiale de la biomasse herba- } \\
\text { cée dans le Parc National du W et dans les terroirs villageois } \\
\text { au Bénin : cas de la Région de Karimama. }\end{array}$ & BIOTA \\
\hline
\end{tabular}

Table 2: Theses in preparation

University of Frankfurt (Germany), PhD-theses

\begin{tabular}{|c|c|c|}
\hline Name & Title & Project \\
\hline Erpenbach, Arne & Termite mounds as islands of diversity in West African savannah landscapes & BIOTA \\
\hline Heubach, Katja & Quantifying ecosystem services and their changes in the West African savannahs & $\mathrm{BiK}-\mathrm{F}$ \\
\hline Heubes, Jonathan & Dynamics of savannah ecosystems in West Africa & BiK-F \\
\hline Jurisch, Katrin & $\begin{array}{l}\text { Research on demography of woody plants in a semi-arid savannah in Northern } \\
\text { Benin }\end{array}$ & SUN \\
\hline Schumann, Katharina & $\begin{array}{l}\text { Vegetation patterns and population dynamics of highly valued species in and } \\
\text { adjacent to the W-National Park, Burkina Faso }\end{array}$ & SUN \\
\hline Tchiengué, Barthelemy & $\begin{array}{l}\text { Secondary successions after shifting cultivation in a dense tropical rain-forest in } \\
\text { Southern Cameroon }\end{array}$ & \\
\hline Zwarg, Alexandra & $\begin{array}{l}\text { Populations structure of important fodder trees in four different climatic regions } \\
\text { of Burkina Faso }\end{array}$ & \\
\hline
\end{tabular}

Research Institute Senckenberg, Frankfurt (Germany), PhD-theses

\begin{tabular}{|l|l|l|}
\hline Name & Title & Project \\
\hline Bocksberger, Gaëlle & Phylogeny and evolution of selected Poaceae of the African savanna biome & BiK-F \\
\hline Kirchmair, Ivana & Diversity and biogeography of gallery forests in West Africa & BIOTA \\
\hline
\end{tabular}

University of Ouagadougou (Burkina Faso), DEA

\begin{tabular}{|l|l|l|}
\hline Name & Title & Project \\
\hline Bayen, Philippe & $\begin{array}{l}\text { Impact des termites sur la restauration des sols et la productivité végétale : cas du } \\
\text { zaï au Yatenga }\end{array}$ & BIOTA \\
\hline Ouédraogo, Issaka & $\begin{array}{l}\text { Fonctions et services des communautés végétales du complexe d'aires protégées } \\
\text { de l'est du Burkina Faso : cas de la Réserve Partielle de Faune de Pama Nord }\end{array}$ & BiK-F \\
\hline
\end{tabular}


University of Ouagadougou (Burkina Faso), PhD-theses

\begin{tabular}{|l|l|l|}
\hline Name & Title & Project \\
\hline Gnoumou, Assan & $\begin{array}{l}\text { Diversité de la flore et de la végétation de la Réserve et Forêt Classée de la Co- } \\
\text { moé-Léraba (Sud-Ouest du Burkina Faso) }\end{array}$ & BIOTA \\
\hline Kaboré G. Elice & $\begin{array}{l}\text { Diversité de la flore et de la végétation des principaux cours d'eau du Burkina } \\
\text { Faso }\end{array}$ & BiK-F \\
\hline $\begin{array}{l}\text { Kagambèga, W. Fran- } \\
\text { çois }\end{array}$ & Restauration écologique des zones dégradées à partir des espèces locales & SUN \\
\hline Koadima, Marcel & $\begin{array}{l}\text { Indicateurs d'utilisation durable de la biodiversité dans le Parc National du W du } \\
\text { Burkina Faso (Sud-Est du Burkina Faso) }\end{array}$ & SUN \\
\hline $\begin{array}{l}\text { Nacoulma, M.Y. } \\
\text { Blandine }\end{array}$ & $\begin{array}{l}\text { Dynamique spatio-temporelle de la phytodiversité du Parc National W du Burki- } \\
\text { na Faso (Sud-Est du Burkina Faso) }\end{array}$ & SUN \\
\hline Sambaré, Oumarou & Diversité de la flore et de la végétation des forêts galeries du Burkina Faso & BIOTA \\
\hline Traoré, Lassina & Dynamique de la flore ligneuse utilitaire de l'Ouest du Burkina Faso & BIOTA \\
\hline
\end{tabular}

University of Abomey-Calavi (Benin), PhD theses

\begin{tabular}{|l|l|l|}
\hline Name & Title & Project \\
\hline Assede, Emeline & Ecology of plant communities in the Biosphere Reserve of Pendjari. & BIOTA \\
\hline Avakoudjo, Julien & $\begin{array}{l}\text { Assessment of soil degradation: Process and resilience as mastered by aridity } \\
\text { factors and land use practices inside and around the W National Park (Benin). }\end{array}$ & SUN \\
\hline Bonou, Alice & $\begin{array}{l}\text { Economic assessment of Non Timber Forest Products (NTFP) in Sampéto, a sur- } \\
\text { rounding village of the W National Park in Banikoara district }\end{array}$ & SUN \\
\hline $\begin{array}{l}\text { Deleke Koko, Kafui } \\
\text { Inès Edna }\end{array}$ & $\begin{array}{l}\text { Ethnobotany and chemical study of galactogenic plants used in traditional medi- } \\
\text { cine in Pendjari Biosphere Reserve. }\end{array}$ & BIOTA \\
\hline $\begin{array}{l}\text { Gouwakinnou, Gérard } \\
\text { N. }\end{array}$ & $\begin{array}{l}\text { Population structure and ethnobotanical uses of Sclerocarya birrea (A.Rich) } \\
\text { Hochst in Karimama district (Benin) }\end{array}$ & SUN \\
\hline Houehanou, Thierry & $\begin{array}{l}\text { Gap analysis : Viability of threatened plant populations (Afzelia africana Smith } \\
\text { ex Pers., Pterocarpus erinaceus Poir., Khaya senegalensis Desr A. Juss; Millicia } \\
\text { excelsa Welw. C. C. Berg) and assessment impacts of Loranthaceae parasite on } \\
\text { Vitellaria paradoxa in Pendjari Biosphere Reserve and in land use area. }\end{array}$ & BIOTA \\
\hline Houessou, Laurent & $\begin{array}{l}\text { Indicators of sustainability at landscape, habitat and species scale for providing a } \\
\text { decision support tool for politician and management workers. }\end{array}$ & SUN \\
\hline
\end{tabular}

Another importat data set is represented by the phytosociological releves (about 3,500) that are documented in the theses of Ataholo (1995, 2001), BöHM (1998), DeHNSCHLAG (1998), HAHN (1996), Kéré (1996), KroHMER (2004), KÜPPERS (1998), MARTIN (1993), MÜLler (2003) and Sieglstetter (2002).

\section{Cooperation With the Research Institute Sen- CKENBERG}

The Senckenberg Gesellschaft für Naturforschung in Frankfurt/M. and its Senckenberg Research Institute have an almost 200 year long history of biodiversity research. The African flora and fauna have been a focus since the days of Eduard Rüppell (1794-1884), one of the pioneers of natural history research in NE Africa. As far as the botanical collections at Senckenberg are concerned, an estimated 300,000 specimens from Africa are housed in the Herbarium Senckenbergianum Frankfurt/M. (FR), which is among the largest European herbaria with far over 1.2 million specimens. These collections were contributed by many collectors, among them Drège, Ecklon, Krauss, Kuls, Schimper, and Zeyher. Unfortunately, the vast majority of these specimens is not digitized and thus cannot be accessed via data- bases or through. the internet. At present, over 15,000 specimens from West Africa in FR are digitized (see also section 6).

In the second half of the $20^{\text {th }}$ century, South Africa and West Africa became the focus of botanical research in Africa. For West Africa, the studies on grasses (Poaceae) by the former head of the Botany-Paleobotany Department, Hans Joachim Conert and his students (e.g. CONERT 1971, 1982; ZIZKA 1988) and the studies on the biodiversity of the Cape Verde Islands are to important, with Wolfram Lobin being one of the principal investigators (e.g. LoBIN 1982, 1984, 1986, 1990, LoBIN \& ZIZKA 1990)

When biological research in Africa at the Goethe University became an important issue with the start of the SFB 268 in 1988 (see 2.1), Senckenberg was the logical partner for expertise in systematics of Poaceae and to house and document the scientific plant collections that were made during the 15 year research period. Some diploma and $\mathrm{PhD}$ theses were supervised in cooperation of botanists from GoetheUniversity and Senckenberg. The longstanding good collaboration between both institutions then led to a cooperation agreement, installing a professorship at the Goethe Univer- 
sity. The tennant of this professorship is at the same time head of the Botany-Paleobotany Department. While Senckenberg was not among the applicants in the SFB 268, the success of this research program and the good and growing cooperation prepared the ground for the successful application in the BIOTA-West program (see 2.4.), where University and Senckenberg were both applicants with specific but strongly interwoven research programs. The excellent contacts between Goethe University and especially the universities of Ouagadougou (Burkina Faso) and Abomey-Calavi (Benin) that had been built up in the times of the SFB 268 (see 2.1) were a prerequisite for the success of the BIOTA program and the project "SUN (see 2.5). Within these programs three diploma theses (GRIMMER 1998, KIRCHMAIR 2009, Zwarg 2008) and one PhD thesis (SCHMidT 2006) were prepared and two further PhD theses initiated (Bocksberger and Kirchmair). Most of the publications originating from BIOTA and SUN with participation of Senckenberg scientists (Dressler, Janssen, Schmidt, Zizka) are already mentioned above $(2.4,2.5)$. Additional publications to be mentioned here are BocKSBERGer et al. (2009), SCHMIDT et al. (2010a,b,c, 2009, 2008b, 2007b, 2005), BRUNKEN et al, (2008a,b), JANSSEN et al. (2008a, b, 2007), Schulte (2007), ZIZKA et al. (2006).

The LOEWE research centre "Biodiversität und Klima" (BiK-F) (for more detailed explanation of projects see 2.6) is the most recent "highlight" of the cooperation of the two institutions and includes various collaborative research projects in western and eastern Africa.

We are focussing here on botanical research, but a zoological aspect of recent Africa research has to be mentioned, too: With the installation of Friedemann Schrenk chairing a cooperation professorship another link between Senckenberg and Goethe University was established. The well known paleoanthropologist and his group investigate the evolution of man and various groups of mammals.

The botanical research projects of Senckenberg in West Africa deal primarily with alpha-diversity and its changes, distribution, biogeography and modelling but extend also to adjacent disciplines. A focus have always been the scientific collections, their accessibility and analysis. The cooperation with our partners therefore always aimed at capacity building in the field of collections and their accessibility. Collection specific efforts have been the digitizing of herbarium collections (SeSam: http://sesam.senckenberg.de) and a by now widely used online foto-database with determination tools (www.westafricanplants.senckenberg.de; see Fig. 1 \& 2). An online-portal standardizing, storing and making available vegetation data is nearing completion and will be online 2010 (www.westafricanvegetation.senckenberg.de).

In the course of a worldwide initiative, types of African plant species have been digitized and can be accessed via the internet, including the types from the Herbarium Senckenbergianum Frankfurt/M. (www.aluka.org; http://plants. jstor.org).

Why are these collection-based internet publications so important? Although internet access in our African partner countries is still not as easy as in Germany, this medium allows cheap and easy access to scientific resources, while journals and other printed products are rare and simply too expensive to be widely used there. Internet portals, -databases and -publications are therefore the tools to be preferably used in the future.

Our joint research projects are progressing towards a checklist of the vascular plants of Burkina Faso (to be published in 2010) and a modern "Flora" of the country. These products form a sound systematic and biogeographic background and together with the analysis of collections are

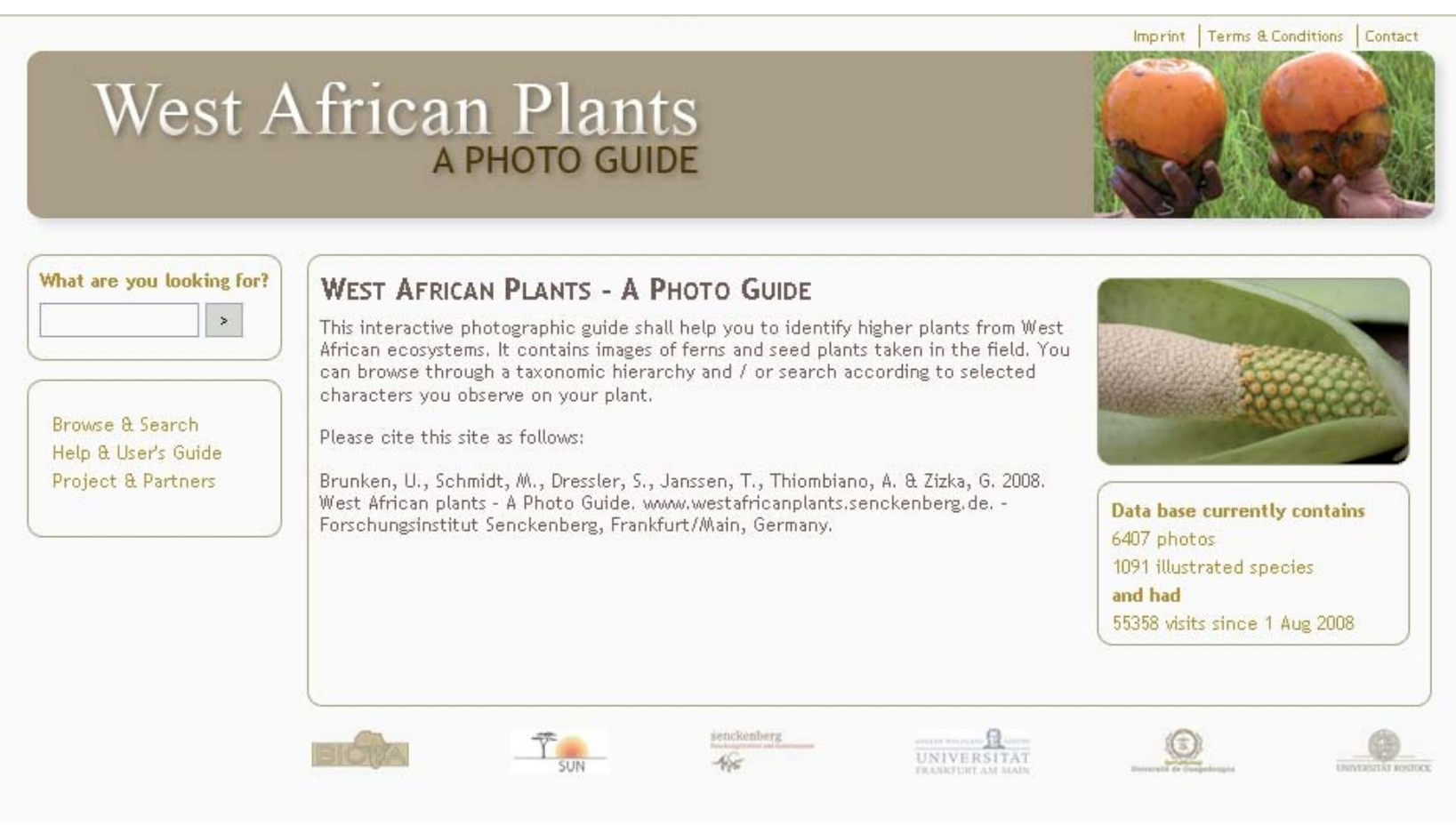

Fig. 1: Homepage of West African Plants - A Photo Guide. www.westafricanplants.senckenberg.de 
essential to link, conserve and analyse local knowledge about the biodiversity. This ranges from the various vernacular names to local plant uses and information about endangerment.

Senckenberg stands not only for biodiversity research and scientific collections but also for "transfer" of scientific results to the public. Media for this are the Senckenberg Natural History Museums in Frankfurt/ Main and Görlitz with their exhibitions and extensive lecture programmes as well as the popular science journals like "Natur und Museum". In the last 20 years many small and some larger exhibitions organized in cooperation with our counterparts as well as numerous popular science articles dealt with African biodiversity and the impact of man and climate on it.

\section{Future Perspectives}

Besides the Cooperation agreement bet-

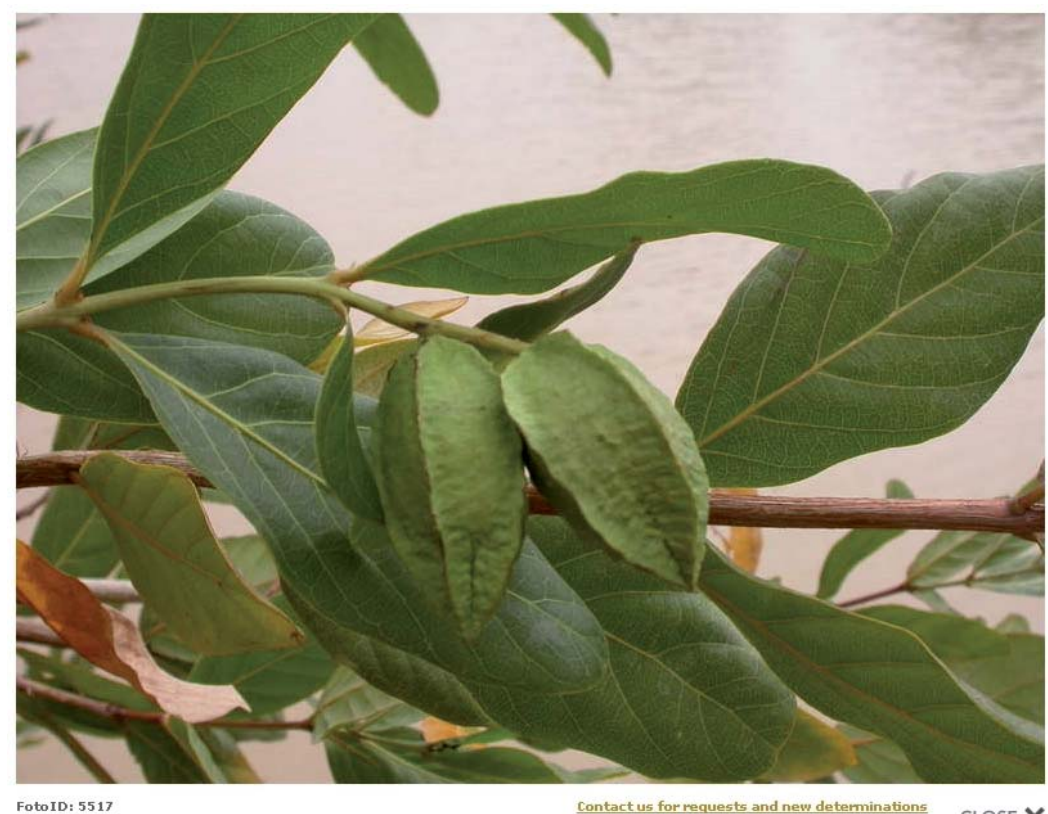
FotoID: 5517 Photographew. Oum acutum M.A.Lawso Photographer: Oumarou Ou Location: Burkina Faso; Tapoa; Arly National Park Image 2 of 2

Fig. 2: Example from the Photo Guide West African Plants. ween the University of Ouagadougou and the University of Frankfurt existing since the start of the SFB 268 in 1988, in 2009 also a cooperation agreement was signed between the University of Abomey-Calavi and the University of Frankfurt. Due to the cooperation professorships mentioned in section 7 this agreement also guaranties the cooperation between the West African Universities and the Research Institute Senckenberg. The LOEWE-Center Biodiversity and Climate Research even offers the chance to enlarge the existing fruitful cooperation between Frankfurt and West Africa. Therefore, the authors have no doubt that the cooperation will last at least another 20 years.

\section{REFERENCES}

Albert K-D \& KüPPERS K (2001): Böden und Vegetation der sahelischen Altdünenlandschaft in NE-Burkina Faso. Ber. SFB 268 17: 161-191. [SFB]

Albert KD, LÖHr D \& Neumann K (eds.)(2004a): Mensch und Natur in Westafrika. - Wiley-VCH Verlag. 537 p. [SFB]

Albert K, Müller J, Ries JB \& Marzolff I (2004b): Aktuelle Landdegradation in der Sahelzone Burkina Fasos. Mensch und Natur in Westafrika. - In AlBerT KD, LöHR D \& Neumann K (Hrsg.): Mensch und Natur in Westafrika. - Ergebnisse aus dem Sonderforschungsbereich "Kulturentwicklung und Sprachgeschichte im Naturraum Westafrikanische Savanne". Weinheim, Wiley-VCH Verlag. pp 289330. $[\mathrm{SFB}]$

Ataholo M \& Wittig R (1995): Segetalvegetation und ausgewählte Bodenparameter gedüngter und ungedüngter Felder in der Provinz Gourma (Burkina Faso, Westafrika). - Verhandl. Ges. Ökol. 24: 31-34. [SFB]

Ballouche A, Küppers K, Neumann K \& WotzKa H-P (1993): Aspects de l'occupation humaine et de l'histoire de la végétation au cours de l'holocène dans la région de la Chaîne de Gobnangou. - Ber. SFB 268 1: 13-31. [SFB]

Bocksberger G, Daget P, Janssen T, Schmidt M, Toutain B, Thiombiano A \& Zizka G (2009): Poaceae distribution

in West Africa: evolution and conservation.- 4 pp.; Tropentag 2009, Univ. Hamburg, Oct. 6-8, 2009: Conference on International Research on Food Security, Natural Resource Management and Rural Development. http://www.tropentag.de/2009/abstracts/links/Bocksberger_qP9jXoDk.pdf

BöHм M (2001): Dorfvegetation im Sahel und Subsahel Burkina Fasos. - Ber. SFB 268 17: 193-225. [SFB]

Braun M, Hahn-Hadjali K \& SChMid S (1995/96): La migration et ses effets sur le mode de gestion de terroir et l'espace naturel dans la province de la Sissili - Burkina Faso. - Rev. Sci. Techn. Sér. Sci. Nat. 22(1): 47-56. [SFB]

BRAUN M, HAHN K \& SCHMID S (1996): Analyse des structures agraires et du couvert végétal de la région de Tô en liaison avec des images satellites multidates. - Ber. SFB 268 7: 33-47. [SFB]

Braun M, Hahn-Hadjali K \& Müller-Haude P (1997): Agrarstruktur und Naturraumpotential in der Provinz Sissili (Burkina Faso). - Ber. SFB 268 9: 67-85. [SFB]

Braun-YaO M \& Hahn-Hadjali K (1999): Migration und lokales Ressourcenmanagement. - In ALBERT E \& ECKERT J (eds.): Settling of Land Conflicts by Mediation/Schlichtung von Landkonflikten - ein workshop -. Institut für Ethnologie, FU Berlin und GTZ, Berlin 15.-17.2.99. Berlin. (CDROM) [SFB]

Braun-Yao M, Hahn-Hadjali K, Schmid S, Sturm H-J, (2000): Analysis of local resource management systems - an interdisciplinary approach. - In RENARD G, KRIEG S, LAWRENCE P \& OPPEN VON M (eds.): Farmers an Scientists in a changing Environment: Assessing Research in WestAfrica. Proceedings of an Regional Workshop. University of Hohenheim, FSA University of Bénin, INRAB, INRAN, Cotonou, Benin 22th - 26th February 1999: 307-317. [SFB]

Brunken U, Schmidt M, Dressler S, Janssen T, ThiomBIANO A \& ZIZKA G (2008a): West African plants - A Photo Guide. URL: www.westafricanplants.senckenberg.de.

Brunken U, Schmidt M, Dressler S, JansSEN T, ThiOMBIANO A \& ZIZKA G (2008b): www.westafricanplants.sen- 
ckenberg.de - An image-based identification tool for West African Plants.- Taxon 57(3): 1027-1028.

Conert HJ (1971): The genus Danthonia in Africa.- Mitt Bot. Staatssamml. München 10: 299-308.

CONERT HJ (Schriftleitung) (1982): Die Ökologie und Bekämpfung des Blutschnabelwebervogels [Quelea quelea (L.)] in Nordostnigeria.- Deutsche Gesellschaft für Technische Zusammenarbeit (GTZ), Eschborn.

CONERT HJ \& LoBIN W (1984): Revision der kapverdischen Sporobolus-Arten (Poaceae).- Garcia de Orta, Sér. Bot. 6: 51-68.

CONERT HJ \& TÜRPE AM (1969): Karroochloa, eine neue Gattung der Gramineen (Poaceae, Arundinoideae, Danthonieae).- Senckenberg. Biol. 50: 289-318.

Demirag U \& Krohmer J (2004): Was Fulbe bewegt - Umweltkonzepte und Handlungsmotive agropastoraler Fulbe in Burkina Faso, Benin und Nigeria. - In AlBERT KD, LÖHR D \& Neumann K (HG.): Mensch und Natur in Westafrika. Weinheim (Wiley), 331-372. [SFB]

Demirag U, GotTschligg P \& Krohmer J (2001): La perception de l'environnement chez les pasteurs Peuls du Nigeria, Burkina Faso et Bénin. - Ber. SFB 268 14: 307321. [SFB]

DRESSLER S (2007): Senckenberg ist Partner der "African Plants Initiative" / Senckenberg as affiliate of the "African Plants Initiative".- In Mosbrugger V (Hrsg.), Senckenberg 2005-2006.-.; Senckenbergische Naturforschende Gesellschaft, Frankfurt a.M., 96 p.

EICHHORN B, Hahn HP \& MÜLler-HAude P (1996): Espace natural, techniques agraires et végétation ségétale en pays Kassena. - Ber. SFB 268 7: 71-81. [SFB]

Gnoumou A, Thiombiano A, Hahn-Hadjali K, AbadouaBOU B, SARR M \& GUINKO S (2008). Le parc Urbain BangrWéoogo: une aire de conservation de la diversité floristique au coeur d'une ville (Ouagadougou, Burkina Faso). - Flora $\&$ Vegetatio Sudano-Sambesica 11: 35-48. [BIOTA]

Hahn-Hadjali K (1998): Pflanzensoziologische Studien der sudanischen Savannen im Südosten Burkina Fasos (Westafrika). - Etude flore veg. Burkina Faso 3: 3-79. [SFB]

Hahn-Hadjali K \& Schmid S (1999): Untersuchungen von Savannengesellschaften der Sudanzone Burkina Fasos (Westafrika) mit multitemporalen SPOT-Satellitendaten. Die Erde 130: 1-16. [SFB]

Hahn-Hadjali K \& Thiombiano A (2001): Perception traditionelle des espèces en voie de disparition en milieu gourmantché: causes et solutions. - Ber. SFB 268 14: 285 297[SFB]

HAHN K \& WiTtig R (1995): Die Vegetationsdynamik auf Brachflächen im Südosten von Burkina Faso (Westafrika). Verhandl. Ges. Ökol. 24: 19-26. [SFB]

Hahn-Hadjali K, Braun-Yao M, Franke-Scharf I \& FrITSCHER N (2001): Interdépendance entre le potentiel d'exploitation et la structure d'habitat dans la région d'Atakora. - Ber. SFB 268 14: 197-207. [SFB]

Hahn-Hadjali K, Schmidt M, König K, Langewiesche K, Kreft H, OuÉdraogo A, Agonyissa D, Thiombiano A, Agbani P, Dressler S, Runge J, Schareika N, Sinsin B, SZARZYNSKI J, WitTIG R \& ZIZKA G (2004): Conservation and sustainable use of biodiversity in West Africa - 3. A case study: changes in phytodiversity through human impact. In Beck E, Berendsohn WG, Boutros M, Denich M, HenLE K, JÜrgens N, KirK M \& Wolters V (eds.). Sustainable use and conservation of biological diversity - A challenge for society. Proceedings of the International Symposium Berlin, 1-4 December 2003, pp.154-157. BMBF, Bonn. [BIOTA]

Hahn-Hadjali K, Bako-Arifari N, Dressler S, Guinko S, Runge J, Schareika N, Sinsin B, Thiombiano A, Wittig R, Zizka G, König K, Schmidt M, Wieckhorst A, Agbani P, Agonyissa D, Anne T, Compaoré I, Korbeogo G, NanSOUNON C, OUedraogo, A, Ouedraogo JB \& Ouedraogo O (2005): Phytodiversity dynamics as an indicator for sustainable use in the West African Sahel and Sudanian Zone.In: BIOLOG Biodiversity \& Global Change Status Report: 132-134; Bonn (PT-DLR Environmental Research \& Technology).

Hahn-Hadjali K, Schmidt M \& Thiombiano A (2006a): Phytodiversity dynamics in pastured and protected West African savannas. In GHAZANFAR SA \& BEENTJE HJ (eds.): Taxonomy and ecology of African plants, their conservation and sustainable use.- Proc. 17th AETFAT Congress, Addis Abeba 21.09.-26.09.2003, 351-359;

Hahn-Hadjali K, Thiombiano A, Dressler S, Schmidt M \& ZizKA G (2006b): Unbekanntes Land am Sahelrand: die Vielfalt von Flora und Vegetation in Burkina Faso. Natur \& Mus. 136(11/12): 256-265.

JANSSEN T, Dressler S, Schmidt M \& ZizKa G (2008): Ein Biodiversitätsdaten-Netzwerk für Westafrika.- Natur \& Mus., 138(5/6): 155.

Kerber D, Reikat A, Specking I \& Sturm H-J (1996): Les terroirs et la végétation. Paradigmes d'exploitation du sol chez les Mosi et les Bisa dans la Province de Boulgou. Ber. SFB 7: 83-91.

KÉRÉ U (1998): Vegetation und Wildpflanzennutzung in der Region Tenkodogo (Burkina Faso). - Etudes flor. veg. Burkina Faso 4: 3-44. [SFB]

KÉRÉ U \& RitZ-MÜLleR U (1995): Krötenbesen und Geisterbohne - Pflanzennamen in Tenkogogo (Burkina Faso). Ber. SFB 268 5: 189-201. [SFB]

Kéré U \& Thiombiano A (1999a): Distribution et Utilisation agroforestière des Combretaceen au Burkina Faso. - Rapport Final Projet TÖB / GTZ, Université de Ouagadougou, Université de Francfort: 107 S. [GTZ]

KÉRÉ U \& Thiombiano A (1999b): Ökologie und Nutzung von Combretaceen in Burkina Faso. - Deutsche Gesellschaft für Technische Zusammenarbeit (GTZ), TÖB-Publikation, Tropenwaldforschung, TÖB-FTWF 13, 87 p.

KÉRÉ U \& WitTig R (1995): Die Gliederung von Landschaft und Vegetation in der Region Tenkodogo (Burkina Faso). Verhandl. Ges. Ökol. 24: 17-18. [SFB]

König K, Runge J, Wegmann M, Schmidt M, Agbani P, AgONYISSA D \& WIECKHORST A (2006): Spatial modelling of changes of the distribution of tree species with LANDSAT satellite data in Benin.- Proc. 6th AARSE International Conference on Earth observation and geoinformation, Cairo.

König K, SChmidT M \& MÜller J (2006): Delineating patterns of plant diversity in the Sahel zone of Burkina Faso: Modelling of environmental envelopes with high resolution remote sensing data.- In RöDER A \& HiLL J (eds.): Proceedings of the first International Conference on Remote Sensing and Geoinformation Processing in the Assessment and Monitoring of Land Degradation and Desertification (RGLDD-05), Trier, Germany, September 7-9 2005, 317323. 
König K, Runge J, Schmidt M, Hahn-Hadjali K, Agbani P, AgONYISSA D \& WieCKHORST A (2008a): The impact of land use on species distribution changes in North Benin. In Runge J (ed.): Dynamics of forest ecosystems in Central Africa during the Holocene: Past - Present -Future. Palaeoecology of Africa 28: 199-226.

König K, Hahn-Hadjali K \& Wittig R (2008b): Wo wächst die Palmyraplame? Mit Satellitendaten praxistaugliche Verbreitungskarten erstellen. - Forschung Frankfurt 3: 75-78. [BIOTA]

KöNIG K, Schmidt M \& MÜLler J (2009): Modelling species distributions with high resolution remote sensing data to delineate patterns of plant diversity in the Sahel zone of Burkina Faso. In RöDER A \& Hill J (eds.): Recent Advances in Remote Sensing and Geoinformation Processing for Land Degradation Assessment. ISPRS Series, 199-210. Taylor \& Francis, London.

Krohmer J (2002): Die Fulbe und ihr liebes Vieh. - In REIKAT A (Hrsg.): Leben in Westafrika. Plexus-Verlag, Frankfurt a. M., 84-91. [SFB]

KroHMER J (2005): Les unités aquatiques de la classification environnementale traditionnelle des Peuls. Exemples du Burkina Faso et Bénin. - Etudes flore vég. Burkina Faso 9: 39-43. [SFB]

KROHMER J (2010): Landscape perception, classification and use among Sahelian Fulani in Burkina Faso (West-Africa) - In JoHnson LM \& HuNN E (eds.): Landscape Ethnoecology. Concepts of Biotic and Physical Space. Berghahn Books [SFB]

Krohmer J \& Sieglstetter R (2002): Der Supermarkt Savanne. - In ReIKAT A (Hrsg.): Leben in Westafrika. PlexusVerlag, Frankfurt a. M., 172-181. [SFB]

Krohmer J, Hahn-Hadjali K \& Wittig R (2006): Utilisation de la flore sauvage par des populations peules au Burkina Faso et Benin. - Etudes flor. vég. Burkina Faso 10: 3348. [SFB]

Krohmer J, Saïdou G, Hahn-Hadjali K, Sinsin B, (2006): A local botanical garden as a tool for sustainability: Conservation of plants and indigenous knowledge in Northern Benin. - Proceedings of the XVIIth AETFAT Congress, Addis Ababa, Ethiopia, 21-26 sept. 2003: 473-480. [SFB, BIOTA]

Krohmer J, Hahn-Hadjali K, Wieckhorst A, Sinsin B, ThiomBiano A (2007): Village Botanic gardens as a tool for preserving plant diversity and indigenous knowledge on a local scale in Benin and Burkina Faso. - Proceedings of the 3. Global Botanic Garden Congress (GBGC): Building a Sustainable Future - the Role of Botanic Gardens. Wuhan, China, 15.-20. April 2007, http://www.bgci.org/files/Wuhan/ PapersConserving/Krohmer.pdf. [BIOTA, SFB]

KÜPPERS K \& MÜller-HAude P (1993): Sols, végétation et occupation du sol dans la région de la Chaine de Gobnangou. - Ber. SFB 268 1: 71-77.

KÜPPERS K \& WitTIG R (1995): Überblick über die Vegetation der Chaîne de Gobnangou (Burkina Faso, Westafrika). - Verhandl. Ges. Ökol. 24: 27-30. [SFB]

Lentz C \& STuRm H-J (2004): Von Bäumen und Erdschreinen. Interdisziplinäre Perspektiven auf die Siedlungsgeschichte der westafrikanischen Savanne. - In ALBERT KD, LÖHR D \& NeumanN K (Hrsg.): Mensch und Natur in Westafrika. - Ergebnisse aus dem Sonderforschungsbereich "Kulturentwicklung und Sprachgeschichte im Naturraum
Westafrikanische Savanne". Weinheim, Wiley-VCH. pp. 400-425.

LOBIN W (1982): Untersuchung über Flora, Vegetation und biogeographische Beziehungen der Kapverdischen Inseln. Dissertation zur Erlangung des Doktorgrades der Naturwissenschaften, Fakultät für Naturwissenschaften und Mathematik der Universität Ulm.- Courier Forschungsinst. Senckenberg 53: 1-112.

LoBIN W (Hrsg.) (1984): 4. Beitrag zur Fauna und Flora der Kapverdischen Inseln. Ergebnisse des 2. Symposiums "Fauna und Flora der Kapverdischen Inseln" (MakaronesienKolloquium).- Courier Forschungsinst. Senckenberg 71: $1-147$.

LoBIN W (1986): The Family Asclepiadaceae on the Cape Verde Islands, West Africa. - Asklepios 37: 73-79.

LoBIN W (Hrsg.) (1990): 8. Beitrag zur Fauna und Flora der Kapverdischen Inseln. Ergebnisse des 4. Symposiums.Courier Forschungsinst. Senckenberg 129: 1-196.

LoBIN W \& ZIZKA G (1990): The impact of Man on the Flora (Phanerogamae) of the Cape Verde Islands.- Mitt. Inst. Allg. Bot. Hamburg 23b: 739-743.

Mbayngone E, Schmidt M, Thiombiano S, Hahn-Hadjali K \& GuInKo S (2008a): Magnoliophyta of the partial faunal reserve of Pama, Burkina Faso. - Check List 4(3): 251-266. [VW]

Mbayngone E, Thiombiano A, Hahn-Hadjali K \& GuinKO S (2008b): Flore et groupements ligneux des formations du Sud-Est du Burkina Faso (Afrique de l'Ouest) : cas de la Réserve de Pama. - Candollea 33(1): 17-33. [VW]

Mbayngone E, Thiombiano A, Hahn-Hadjali K \& Guinko $\mathrm{S}$ (2008c): Structure des ligneux des formations végétales de la Réserve de Pama (Sud-Est du Burkina Faso, Afrique de l'Ouest). - Flora Vegetatio Sudano-Sambesica 11: 25-34. [VW]

Mbayngone E, Thiombiano A, Hahn-Hadjali K \& Guinko S (2008d): Caractéristiques écologiques de la flore ligneuse des formations du Sud-Est du Burkina Faso (Afrique de l'Ouest): cas de la réserve de Pama. - Candollea-Boisseria 63(1): 17-33. [VW]

Mischung R, Nierste-Klausmann G, Ritz-Müller U, SCHÖlL U (1993): L'homme et l'ènvironnement chez les Mossi de Tenkodogo. - Ber. SFB 268 1: 111-115. [SFB]

MüLleR J \& Wittig R (2002): L'état actuel du peuplement ligneux et la perception de sa dynamique par la population dans le Sahel burkinabé - présenté à l'exemple de Tintaboora et de Kollangal Alyaakum. - Etudes flore veg. Burkina Faso 6: 19-30. [SFB]

MÜLLER JV \& WitTIG R (2004): The Importance of Acacia L. (Mimosaceae) for the vegetation in the Sahelian Region of Burkina Faso. - Etudes flor. veg. Burkina Faso 8: 27-38. [SFB]

NEUMANN K (2009): Archaeobotanical Research of the SFB 268 in West Africa. - Flora Vegetatio Sudano-Sambesica 12: 22-26.

Neumann K, Hahn-Hadjali K \& Salzmann U (2004): Die Savannen der Sudanzone in Westafrika - natürlich oder menschengemacht? - In AlberT KD, LöHr D \& NeumanN K (Hrsg.): Mensch und Natur in Westafrika. - Ergebnisse aus dem Sonderforschungsbereich "Kulturentwicklung und Sprachgeschichte im Naturraum Westafrikanische Savanne". Weinheim, Wiley-VCH. 39-68. [SFB] 
Ouedraogo A, Thiombiano A, Hahn-Hadjali K \& Guinko S (2006a): Diagnostic de l'état de dégradation des peuplements de quatre espèces ligneuses en zone soudanienne du Burkina Faso. - Sécheresse, 17(4): 485-491. [BIOTA]

Ouedraogo A, Thiombiano A, Hahn-Hadjali K \& GuinKO S (2006b): Régénération sexuée de Boswellia dalzielii Hutch., un arbre médicinal de grande valeur au Burkina Faso. - Bois et Forêts des Tropiques, 289 (3): 41-48. [BIOTA]

Ouedraogo A, Thiombiano A, Hahn-Hadjali K \& GuinKo $S$ (2006c): Structure du peuplement juvénile et potentialités de régénération des ligneux dans l'Est du Burkina Faso. Etudes flor. vég. Burkina Faso 10: 17-24. [BIOTA]

OuÉdraogo O, Thiombiano A, Hahn-Hadjali K \& Guinko S (2008a): Diversité et structure des groupements ligneux du Parc National d'Arly (Est du Burkina Faso). - Flora Vegetatio Sudano-Sambesica 11: 5-16. [BIOTA]

Ouedraogo O, Thiombiano A, Hahn-Hadjali K \& GuinKo S (2008b): Diversité et structure des formations ligneuses du Parc National d'Arly (Est du Burkina Faso). - Flora Vegetatio Sudano-Sambesica 11: 5-16. [BIOTA]

OuÉdraogo O, Thiombiano A, Hahn-Hadjali K \& GuinKO S (2009): Flore et potentialities de regeneration de la végétation juvénile des groupements végétaux ligneux dans le Parc National d'Arly à l'Est du Burkina Faso. - Candollea 64: 257-278. [BIOTA]

Ouedraogo RL, Guinko S \& WitTig R (2005): La végétation aquatique et semi-aquatique du Mare aux Hippopotames et des Mares d'Oursi et Yomboli (Burkina Faso). - Etudes flor. veg. Burkina Faso 9: 19-33.

Pelzer C, Müller J \& Albert KD (2004): Die Nomadisierung des Sahel - Siedlungsgeschichte, Klima und Vegetation in der Sahelzone von Burkina Faso in historischer Zeit. - In Albert KD, LöHr D \& NeumanN K (Hrsg.): Mensch und Natur in Westafrika. - Ergebnisse aus dem Sonderforschungsbereich "Kulturentwicklung und Sprachgeschichte im Naturraum Westafrikanische Savanne". Weinheim, Wiley-VCH, 256-288. [SFB]

REIKAT A (ed.)(2003): Leben in Westafrika. - J.W. - GoetheUniversität, Frankfurt, 197 p. [SFB]

Reikat A, Moldenhauer K-M, Sturm, H.-J. \& Tiando, E. (2001): Étapes de l'histoire du peuplement dans la région de l'Atakora. - Ber. SFB 268 14: 223-228. [SFB]

Schmid, S., Braun-YaO M, Hahn-Hadjali K, \& WerthMANN K, (2001): L'impact du droit foncier sur l'utilisation des ressources naturelles. Le cas d'un ancien projet d'installation de migrants (AVV) dans le sud-ouest du Burkina Faso. - Ber. SFB 268 14: 535-542. [SFB]

Schmidt M, Kreft H, Thiombiano A \& Zizka G (2005): Herbarium collections and field data based plant diversity maps for Burkina Faso. - Diversity and Distributions 11: 509-516.

Schmidt M, Kreft H, Thiombiano A \& Zizka G (2007a): Indicator value of different vascular plant families for overall plant diversity in the savanna belt of Western Africa.Ecotropica 13: 135-142.

Schmidt M, ZizKa G \& Dressler S (2007b): Das BIOTA Afrika Projekt - Erforschung der Biodiversität in Westafrika / The BIOTA Africa Project - Investigating biodiversity in West Africa.- In Mosbrugger, V. (Hrsg.), Senckenberg 2005-2006.- Senckenbergische Naturforschende Gesellschaft, Frankfurt a.M, 96 p.
Schmidt M, Brunken U, Dressler S, Janssen T \& Zizka G (2008a): www.westafricanplants.senckenberg.de - Eine Fotodatenbank zu westafrikanischen Pflanzen.- Natur \& Mus. 138(9/10): 247.

Schmidt M, KöNIG K \& MÜLler JV (2008b): Modelling species richness and life form composition in Sahelian Burkina Faso with remote sensing data. - J. Arid Environments. http://dx.doi.org/10.1016/j.jaridenv.2008.02.015. [BIOTA]

Schmidt M, Brunken U, Dressler S, Janssen T, PorembSKi S, Thiombiano A \& ZiZKA G (2009, publ. online): West African Plant Database - a photoguide and identification tool.- 4 pp.; Tropentag 2009, Univ. Hamburg, Oct. 6-8, 2009: Conference on International Research on Food Security, Natural Resource Management and Rural Development.

Schmidt M, Thiombiano A, Ouédraogo A, Dressler S, Hahn-Hadjali K \& ZizKa G (2010a): Assessment of the flora of Burkina Faso. Proceedings of the 18th AETFAT Congress, 26.02.-02.03.2007 at Yaoundé, Cameroon. Kew Publishings, Royal Botanic Gardens Kew, pp. 571-576.

Schmidt M, Agonyissa D, OuÉdraogo A, Hahn-Hadjali K, Thiombiano A, Koulibaly A, Goetze D \& Zizka G (2010b). Changes in plant species composition following a climatic gradient in West Africa. - Proceedings of the 18th AETFAT Congress, 26.02.-02.03.2007 at Yaoundé, Cameroon. Kew Publishings, Royal Botanic Gardens Kew, pp. 823828. [BIOTA]

Schmidt M, Thiombiano A, Dressler S, Hahn-Hadjali K, Guinko S \& ZizKA G (2010c). Phytodiversity data strengths and weaknesses. A comparison of collection and relevé data from Burkina Faso. - Proceedings of the 18th AETFAT Congress Yaounde march 2007. Kew Publishings, Royal Botanic Gardens Kew, pp. 829-837. [BIOTA]

Schulte K (2007): Eine Bromelie in Afrika: Wie gelangte Pitcairnia feliciana nach Guinea? - Bromelie 2007 (1): 1215.

Sieglstetter R \& Wittig R (2002): L'utilisation des ligneux sauvages et son effet sur la végétation dans la région d'Atakora (Bénin nord-occidental). - Etudes flore veg. Burkina Faso 7: 23-30. [SFB]

STURM H-J (1995): Das Überweidungsproblem in der westafrikanischen Savanne. Neue Ansätze und Perspektiven. - Ber. SFB 268 5: 163-176. [SFB]

STURM H-J (1997a): Kulturbaumparks in der Provinz Boulgou (Burkina Faso). - Ber. SFB 268 9: 169-188. [SFB]

STURM H-J (1997b): Nutzbäume in der westafrikanischen Savanne: Der Schibutterbaum (Vitellaria paradoxa C.F. Gaertn.) - Charakterbaum der Sudanzone. - Der Palmengarten 97(1): 41-48. [SFB]

STURM H-J (1998a): Development and dynamics of agricultural parks in West Africa. - In KIRBY K \& WATKINS C (eds.): The ecological history of European forests. CAB International, Wallingford. [SFB]

STURM H-J (1998b): The importance of agricultural parks for soil fertility management. - In RENARD G, NEEF A, BECKER K \& OPPEN M VON (eds.): Soil fertility management in the West African land use systems, 4-8 March 1997, Niamey. - Margraf Verlag, Weikersheim, pp 293-298. [SFB]

Sturm H-J (2001a): Entre la savane et la forêt - Histoire de l'environnement dans quelques paysages culturaux au Bénin. - Ber. SFB 268 14: 193-196. [SFB] 
StURm H-J (2001b): Les parcs agraires: reflet de l'histoire du peuplement. - Ber. SFB 268, Bd. 14, Frankfurt am Main, S. 405-408. [SFB]

Sturm H-J, Franke I, Kirscht H, Ataholo M \& SkorUPINSKI T (1996): Natural environment and land use in the chad basin, NE-Nigeria. Preliminary of an interdisciplinary research. - Ber. Sonderforschungsbereich 268 8: 335-348. [SFB]

Sturm H-J, Denschlag J, Gottschligg P, Hahn-Hadjali K, KROHMER J \& WitTIG R (1999): They must have their very own reasons - environmental perception of the Fulani in West Africa. - Procc. VIth International Rangeland Congress, Townsville. Vol 1, 73-74. [SFB]

Thiombiano A, Millogo-Rasolodimby J \& Guinko S (1995): Descriptions et importances socio-économiques de quelques espèces du genre Terminalia. - Etudes flor. veg. Burkina Faso 2: 25-32. [SFB]

Thiombiano A, Millogo-Rasolodimby J \& Guinko S (1996): Etude des caractéristiques botaniques de Pteleopsis suberosa Engl. \& Diels (Combretaceae) de la région est du Burkina Faso. - Rev. Sci. Techn. 22(1): 75 - 82. [SFB]

Thiombiano A, Millogo-Rasolodimby J \& Guinko S (1997): Caractéristiques botaniques de Combretum nioroense (Combretaceae) de la région est du Burkina Faso. - Ann. Université Ouagadougou, Sér. B, 5: 157 -165. [GTZ]

Thiombiano A, Millogo J \& GuinKo S, (1998): Etude des caractéristiques botaniques des Combretaceae de l'Est du Burkina Faso. - Acta Biol. Benrodis 9: 45 - 54. [GTZ]

Thiombiano A, Hahn-Hadjali K \& Wittig R (1999): Phytosociologie et écologie des Combretaceae à l'Est du Burkina Faso (Afrique de l'Ouest) le long d'un gradient pluviométrique. - Doc. Phytosoc. 19: 337-348. [GTZ]

Thiombiano A, Millogo-Rasolodimby J \& Guinko S (2001): Anatomical study of Terminalia (Combretaceae) species collected from eastern Burkina Faso. - Ann. Bot. Afr. O., 00(1): 43-52. [SFB]

Thiombiano A, Ouoba P \& Guinko S (2002): Place des Combretaceae dans la société gourmantché à l'Est du Burkina Faso. - Etudes flor. veg. Burkina Faso 7: 17-22. [GTZ]

Thiombiano A, Wittig R \& Guinko S (2003): Conditions de la multiplication sexuée chez des Combretaceae du Burkina Faso. - Rev. Ècol. (Terre Vie) 58: 361-379. [GTZ]

Thiombiano A, Schmidt M, Kreft H, Guinko S, (2006): Influence du gradient climatique sur la distribution des espèces de Combretaceae au Burkina Faso (Afrique de l'Ouest). - Candollea 61(1): 189-213. [BIOTA]

Thiombiano A, Da S \& Hahn-Hadjali K, (2007): Réhabilitation de zones dégradées au Burkina Faso à base d'espèces locales. - In Mayaka TB, De Fongh H \& Sinsin B (eds.) : Ecological Restoration of Acrican Savanna Ecosystems. Proceedings of the third RNSCC International Seminar, 6th Feb, Cotonou, Benin. CEDC/CML, Leiden University. [BIOTA]

Wala K, Sinsin B, Hahn-Hadjali K, Akpagana K, (2006): Tree species diversity as related to topography and human activities in the Atakora mountains in Benin. - Proceedings of the 17th AETFAT Congress, Addis Ababa (21.09.26.09.2003), Royal Botanic Gardens, 339-350. [BIOTA]

WitTig R (2005a): The syntaxonomy of the aquatic vegetation of Burkina Faso. - Etudes flor. veg. Burkina Faso 9: 3-10.
WitTig R (2005b): Echinochloetea colonae classis nova. Etudes flor. veg. Burkina Faso 9: 11-18.

WitTIG R \& MARTIN R (1995): Die krautigen Wildpflanzen zweier Siedlungen in der Provinz Tapoa (Burkina Faso) und ihre Nutzung für die menschliche Ernährung. - Ber. SFB 268 5: 203-212. [SFB]

WitTig R \& MARTin R (1998): Sammeln und Verkauf von Wildpflanzen als Einkommensquelle der Frauen in der Provinz Tapoa (Burkina Faso). - Etudes flor. veg. Burkina Faso 3: 81-88. [SFB]

Wittig R, Hahn K, KÜPPERS K \& SchÖLl U (1992): Geound ethnobotanische Untersuchungen im Südosten von Burkina Faso. - Geobot. Kolloq. 8: 35-52. [SFB]

Wittig R, Hahn-Hadjali K \& StURM H-J (1998): Botanical Research in Burkina Faso as part of the Interdisciplinary Research Programme of the University of Frankfurt. - SEREIN Occasional Paper $N^{\circ}$ 6: 179-183. [SFB]

Wittig R, Hahn-Hadjali K \& Thiombiano A (2000): Besonderheiten von Flora und Vegetation der Chaîne de Gobnangou und ihres Umlands im Südosten Burkina Fasos. Etudes flore vég. Burkina Faso 5: 49-64. [SFB]

Wittig R, Hahn-Hadjali K, Krohmer J \& MÜller J (2000): Nutzung, Degradation und Regeneration von Flora und Vegetation in westafrikanischen Savannenlandschaften. - Ber. Reinh.-Tüxen-Ges. 12: 263-281. [SFB]

Wittig R, Hahn-Hadjali K, Krohmer J, Müller J \& Sieglstetter R (2002): La végétation actuelle des savanes du Burkina Faso et du Bénin - sa signification pour l'homme et la modification de celle-ci par l'homme. - Etudes flor. veg. Burkina Faso 7: 3-16. [SFB]

Wittig R, Devineau J-L \& Fournier A (2004a): L'importance du genre Acacia L. (Mimosacées) pour la végétation du secteur soudanien du Burkina Faso. - Etudes flor. veg. Burkina Faso 8, 45-50. [BIOTA]

Wittig R, Schmidt M \& Thiombiano A (2004b): Cartes de distribution des espèces du genre Acacia L. au Burkina Faso. - Etudes flor. veg. Burkina Faso 8: 19-26. [BIOTA]

Wittig R, Hahn-Hadjali K, König K, Schmidt M, SzarZYNSKI J \& THIOMBIANo A (2006): Dynamik von Flora und Vegetation der westafrikanischen Sudanzone am Beispiel von Burkina Faso. - Ber. Reinh.-Tüxen-Ges 18: 57-68. [BIOTA]

WitTig R, KÖNIG K, Schmidt M \& SZARZYNSKi J (2007): A Study of Climate Change and Anthropogenic Impacts in West Africa. - Env Sci Pollut Res 14, 182-189. http://dx.doi. org/10.1065/espr2007.02.388. [BIOTA]

ZizKa G (1988): Revision der Melinideae Hitchcock (Poaceae, Panicoideae).- Biblioth. Bot. 138: 1-149.

ZizKA G (1989): Melinideae.- In LAUNERT E (ed.): Flora Zambesiaca 10,3: 113-128.

ZizKa G (1990): Taxonomy of the Melinideae (Poaceae, Panicoideae).- Mitt. Inst. Allg. Bot. Hamburg 23b: 563-572.

ZıZKA G (1996): Melinideae.- In PhILLIPS S (ed.): Flora of Ethiopia and Eritrea: Poaceae (Gramineae) 7: 185-191; Addis Ababa und Uppsala.

ZiZKa G, Dressler S \& Schmidt M (2006): Afrika-Forschung bei Senckenberg.- Forschung Frankfurt 2-3: 20.

Zwarg A, Schmidt M \& Hahn-Hadjali K (2008): Vitrine September/ Oktober 2008: Der Sheabutterbaum.- Natur \& Mus. 138(9/10): 242. 


\section{Adresses of the Authors}

\section{Rüdiger Wittig}

\section{Karen Hahn-Hadjali}

Institute of Ecology, Evolution and Diversity Goethe-Universität

Siesmayerstraße 70

D-60323 Frankfurt am Main

Germany

eMail: r.wittig@em.uni-frankfurt.de

\section{Georg Zizka}

\section{Stefan Dressler}

Research Institute Senckenberg \&

Institute of Ecology, Evolution and Diversity Goethe-Universität

Senckenberganlage 25

D-60325 Frankfurt am Main

Germany

eMail: Georg.Zizka@senckenberg.de eMail: stefan.dressler@senckenberg.de

\section{Adjima Thiombiano}

\section{Sita Guinko}

Unité de Formation et de Recherche en Sciences de la Vie et de la Terre

Laboratoire de Biologie et Ecologie Végétales

Université de Ouagadougou

03 BP 7021 Ouagadougou

Burkina Faso

eMail: adjima thiombiano@univ-ouaga.bf eMail: sguinko@@univ-ouaga.bf

\section{Brice Sinsin}

Faculté des Sciences Agronomiques

Université d'Abomey-Calavi

01 BP 526 Cotonou

Bénin

eMail: brice.sinsin@fsa.uac.bj 